\title{
Peningkatan Prestasi Belajar PKN Materi Kebebasan Berorganisasi dengan Metode Card Sort pada Siswa Kelas V SD Negeri 1 Karangsoko Kecamatan Trenggalek
}

\author{
Dwi Suryandari \\ SD Negeri 1 Karangsoko Kecamatan Trenggalek, Indonesia \\ Email : dwi.suryandari@gmail.com
}

\begin{abstract}
Abstrak: Melalui pengamatan yang dilakukan di kelas $\mathrm{V}$ SDN 1 Karangsoko Kecamatan Trenggalek, ditemukan bahwa kemampuan siswa dalam menguasai mata pelajaran PKn tergolong rendah. Salah satu sebab rendahnya prestasi belajar siswa adalah karena metode pembelajaran yang digunakan cenderung monoton dan kurang variatif. Salah satu pemecahan masalah yang digunakan peneliti adalah dengan menggunakan metode card sort. Tujuan penelitian ini adalah untuk mengetahui gambaran obyektif tentang peningkatan prestasi belajar PKn materi kebebasan berorganisasi dengan metode card sort Tersedia Online di http://journal.unublitar.ac.id/pendidi kan/index.php/Riset_Konseptual

Sejarah Artikel

Diterima pada : 05-01-2020

Disetuji pada : 29-01-2020

Dipublikasikan pada : 31-01-2020

Kata Kunci:

Prestasi belajar, PKn, Metode Card Sort DOI:

http://doi.org/10.28926/riset_konseptual.v4i 1.175

pada siswa kelas $\mathrm{V}$ SD Negeri 1

Karangsoko Kecamatan Trenggalek semester II tahun pelajaran 2018 / 2019.

Jenis penelitian ini adalah Penelitian Tindakan Kelas (PTK). Hasil analisis terhadap peningkatan hasil dan ketuntasan belajar siswa menunjukkan bahwa pada pra siklus sebanyak 6 siswa (40,00\%), siklus I sebanyak 9 siswa $(60,00 \%)$ dan siklus II sebanyak 13 siswa $(86,67 \%)$. Sedangkan pencapaian nilai rata-rata kelas pada pra siklus adalah 66,33 , siklus I adalah 73,00, pada siklus II adalah 83,00. Berdasarkan hasil penelitian dapat disimpulkan bahwa penerapan metode card sort dapat meningkatkan prestasi belajar siswa pada Kelas $\mathrm{V}$ SDN 1 Karangsoko Kecamatan Trenggalek Kabupaten Trenggalek
\end{abstract}

\section{PENDAHULUAN}

Pendidikan Kewarganegaraan (PKn) merupakan salah satu mata pelajaran yang dapat meningkatkan kualitas Sumber Daya Manusia (SDM), karena dalam mata pelajaran PKn terdapat materi tentang nilai moral yang penting untuk kemajuan SDM. $\mathrm{PKn}$ sendiri adalah mata pelajaran yang di gunakan sebagai wahana untuk mengembangkan dan melestarikan nilai luhur dan moral yang berakar pada budaya bangsa Indonesia. Nilai luhur dan moral ini di harapkan dapat di wujutkan dalam bentuk perilaku kehidupan siswa sehari-hari, baik sebagai individu maupun anggota masyarakat, dan makhluk ciptaan Tuhan Yang Maha Esa, yang merupakan usaha untuk membekali siswa dengan pengetahuan dan kemampuan dasar berkenaan dengan hubungan antar warga dengan negara serta pendidikan pendahuluan bela negara agar menjadi warga negara yang dapat diandalkan oleh bangsa dan negara (Ahmad Susanto, $2013: 225$ ).

Melalui pengamatan yang dilakukan di kelas V SDN 1 Karangsoko Kecamatan Trenggalek, ditemukan bahwa kemampuan siswa dalam memahami mata pelajaran $\mathrm{PKn}$ tergolong masih rendah. Nilai kriteria ketuntasan mengajar (KKM) untuk mata pelajaran PKn sebesar 75. Berdasarkan hasil observasi awal diketahui bahwa dari sejumlah 15 siswa, terdapat 6 siswa atau 40,00\% memperoleh nilai sesuai KKM dan 9 siswa yang lain belum memenuhi KKM yang ditentukan. Faktor dari siswa dan guru 
merupakan salah satu penyebab rendahnya kemampuan dalam pembelajaran PKn. Daya ingat yang kurang merupakan faktor yang disebabakan oleh siswa. Sedangkan kurangnya kreativitas guru dalam menggunakan metode pembelajaran yang efektif dan efisien adalah factor dari guru kelas. Dalam kegiatan pembelajaran di kelas guru masih setia menggunakan metode konvensional secara monoton, sehingga terciptalah suasana kelas yang terbilang kaku dan di dominasi oleh guru contohnya metode ceramah. Metode ceramah adalah cara menyajikan pelajaran melalui penuturan secara lisan atau penjelasan langsung kepada kelompok siswa (Sanjaya, 2006: 147). Selain itu metode ceramah merupakan metode yang membuat siswa bersikap pasif dikarenakan siswa hanya diminta untuk mendengarkan keterangan dari guru. Oleh karena itu, berimbaslah pada rendahnya hasil belajar siswa terutama pada materi memahami kebebasan berorganisasi. Dampak ini dapat diatasi dengan pemilihan metode yang tepat dan sesuai dengan materi yang akan di sampaikan.

Menurut peneliti metode yang tepat untuk mata pelajaran PKn khususnya materi memahami kebebasan berorganisasi adalah dengan metode Card Sort. Metode ini merupakan suatu kegiatan kolaboratif yang biasa digunakan untuk mengajar konsep, karakteristik klasifikasi, fakta tentang obyek atau mereview informasi. Gerakan fisik yang dominan dalam strategi ini dapat membantu mengurangi rasa jenuh atau bosan di kelas (Hisyam, 2002: 50). Dengan metode tersebut siswa dituntut untuk lebih aktif, berfikir cepat dan tepat. Metode Card Sort sebagai salah satu cara yang menyenangkan dan membuat aktif siswa untuk meninjau ulang materi yang telah di sampaikan sebelumnya. Dalam buku Sobary Sutikno (2014: 130-131) Metode mensortir kartu ini (Card Sort) di gunakan oleh peserta didik dengan maksud mengajak peserta didik untuk menemukan konsep dan fakta melalui klasifikasi materi yang di bahas dalam pembelajaran. Tujuan dari metode mensortir kartu ini adalah untuk mengungkapkan daya ingat terhadap materi pelajaran yeng telah dipelajari di kelas.

Berdasarkan rumusan masalah yang di kemukakan di atas, maka tujuan penelitian ini adalah: untuk mendapatkan gambaran obyektif tentang peningkatan prestasi belajar PKn materi kebebasan berorganisasi dengan metode card sort pada siswa kelas V SD Negeri 1 Karangsoko Kecamatan Trenggalek semester II tahun pelajaran 2018 / 2019. Manfaat penelitian ini adalah untuk meningkatkan prestasi belajar siswa dengan cara pemberdayaan metode pembelajaran yang lebih baik.

\section{METODE}

Penelitian ini menerapkan model penelitian dari Kemmis dan Mc Taggart (1992) yakni penelitian tindakan kelas. Terdapat dua siklus yang tiap siklusnya terdiri atas empat sub kegiatan, diantaranya perencanaan (plan), pelaksanaan tindakan (action), observasi (observation), dan refleksi (reflection). Penelitian ini berisi bagaimana sekelompok guru dapat mengorganisasikan kondisi praktek pembelajaran mereka, dan belajar dari pengalaman mereka sendiri. Mereka dapat mencoba suatu gagasan perbaikan dalam praktek pembelajaran mereka, dan melihat pengaruh nyata dari upaya itu (Rochiati, 2008 : 13). Subjek pada penelitian ini terdiri dari Siswa kelas V SDN 1 Karangsoko Kecamatan Trenggalek Kabupaten Trenggalek pada semester 2 tahun pelajaran 2018/2019 dengan jumlah 38 siswa, 21 siswa laki-laki dan 17 siswa perempuan. Metode pengumpulan data pada penelitian ini berupa tes tulis yang terdiri dari beberapa soal. Sedangkan analisis data menggunakan analisis dan refleksi dalam setiap siklusnya. Penelitian ini menggunakan analisis deskriptif.

\section{Pra Siklus}

\section{HASIL DAN PEMBAHASAN}

Sebelum menggunakan metode Card Sort, penyampaian materi menggunakan metode ceramah tanpa media. Dari hasil observasi sebelum penerapan metode Card Sort didapatkan nilai sebagai pembanding setelah dan sebelum penerapan metode Card Sort sebagai pemecah masalah. Nilai dalam 
penelitian ini sebagai indikator tingkat pencapaian penggunaan metode Card Sort untuk meningkatkan prestasi belajar siswa. Sebagai patokan adalah nilai Kriteria Ketuntasan Minimum (KKM) kelas V SDN Karangsoko, pada mata pelajaran Pendidikan Kewarganegaraan yaitu 75 . Nilai siswa dari pra siklus dapat terlihat pada table 4.1 sebagai berikut:

Table 4.1 Rekapitulasi Nilai Siswa Pra Siklus

\begin{tabular}{|c|c|c|c|c|c|}
\hline No & Skor & Jumlah Siswa & Persentase & Kriteria & Ket \\
\hline 1 & $85-100$ & 0 & 0,00 & Tinggi & T \\
\hline 2 & $75-84$ & 12 & 31,58 & Sedang & T \\
\hline 3 & $65-74$ & 11 & 28,95 & Cukup & BT \\
\hline 4 & $\leq 65$ & 15 & 39,47 & Kurang & BT \\
\hline \multicolumn{2}{|c|}{ Jumlah } & 38 & 100,00 & - & - \\
\hline \multicolumn{5}{|c|}{ \%etuntasan } & 31,58 \\
\hline \multicolumn{4}{|c|}{ Rata-rata } & 66,18 \\
\hline
\end{tabular}

Dari data di atas dapat disimpulkan bahwa siswa yang tuntas dalam KKM 75 sebanyak 12 siswa atau $31,58 \%$. Sedangkan yang belum tuntas sebanyak 26 siswa atau $68,42 \%$ dari jumlah siswa yang ada di kelas V SDN 1 Karangsoko Kecamatan Trenggalek . Nilai rata-rata kelasnya adalah $66,18 \%$.

\section{Siklus I}

Pelaksanaan tindakan pada siklus I di laksanakan pada semester II, pada tanggal 15 Februari 2019 dan 26 Februari 2019. Pelaksanaan tindakan ini sesuai dengan program semester mata pelajaran Pendidikan Kewarganegaraan kelas $\mathrm{V}$ Semester II, standar kompetensi Memahami Kebebasan Berorganisasi, dengan kompetensi dasar mendeskripsikan pengertian organisasi. Ada 4 (empat) tahapan dalam siklus ini, yaitu dengan alur perencanaan (planning), implementasi tindakan (acting), observasi dan interpretensi (observing), dan refleksi (reflekting), dengan ulasan sebagai berikut:

\section{a. Perencanaan}

Pada tahap ini peneliti merencanakan :

1) Guru menyiapkan Rencana Program Pembelajaran PKn pokok bahasan memahami kebebasan berorganisasi dengan penerapan metode Card Sort.

2) Mempersiapkan perlengkapan pembelajaran Card Sort dengan lebih baik.

3) Mempersiapkan soal-soal PKn bahasan mendiskripsikan pengertian berorganisasi sebagai sarana untuk mengetahui kemampuan siswa.

4) Mempersiapkan lembar observasi untuk guru guna mengetahui atau mendapatkan data perubahan dan perkembangan tentang penerapan metode Card Sort.

5) Mempersiapkan lembar observasi untuk guru guna mengetahui pelaksanaan metode Card Sort dalam pembelajaran di kelas.

b. Tindakan

\section{Pertemuan I dan II}

Kegiatan awal dimulai dengan guru memberi salam dan mengabsen kehadiran siswa. Selanjutnya guru mengajak siswa membaca basmalah bersama-sama sebelum pelajaran di mulai. Guru dibantu kolaborator menyiapkan peralatan pembelajaran Card Sort. Sebelum masuk pada kegiatan inti guru memberi penjelasan tentang jalannya metode pembelajaran Card Sort.

Memasuki kegiatan inti diawali dengan guru menjelaskan kepada siswa pengetian organisasi dan menjelaskan ciri-ciri organisasi kepada 
siswa. Selama proses pembelajaran guru melibatkan siswa secara aktif dalam setiap kegiatan. Guru menjelaskan permainan Card Sort kepada siswa.

Permainan diawali dengan guru membagi potongan kertas berisi materi yang di sampaikan kepada siswa. Selanjutnya siswa diminta mencari pasangan yang sesuai dengan materi yang di sampaikan. Jika sudah ada yang ketemu pasangannya, siswa membentuk satu kelompok. Selanjutnya setiap kelompok mempresentasikan hasilnya. Setelah itu dilanjutkan dengan sesi tanya jawab kemudian guru menjelaskan hal-hal yang belum di ketahui siswa dan diakhiri dengan menyimpulkan materi yang telah disampaikan.

Di akhir pembelajaran guru memberi refleksi terhadap kegiatan yang sudah di laksanakan dan memberikan umpan balik terhadap proses dan hasil pembelajaran. Kemudian ditutup dengan membaca hamdalah bersama-sama dan guru mengucapkan salam.

\section{c. Pengamatan}

Hasil pengamatan atau observasi di lapangan pada siklus I ini, masih banyak kelemahan- kelamahan, di antaranya sebagai berikut, guru kurang keras dalam mengucapkan salam, guru kurang jelas dalam memberikan instruksi terhadap metode Card Sort. Pengelolaan waktu yang kurang optimal, karena ada siswa yang belum selesai mempresentasikan materi waktu sudah habis.Dari aktivitas belajar siswa, siswa kurang serius dalam memperhatikan guru, siswa masih malu-malu bersama kelompoknya menempel kartu dalam pembelajaran, siswa belum banyak berpartisipasi dalam diskusi kelompok.

\section{d. Refleksi}

Dari hasil belajar siswa, terjadi peningkatan kemampuan pemahaman. Hal ini di lihat dari nilai tes siswa. Dari 38 siswa, sebanyak 24 siswa atau $63,16 \%$ dari siswa tuntas dalam pembelajaran, dan 14 siswa atau $36,84 \%$ tidak tuntas dalam pembelajaran. Nilai rata-rata pada siklus I hanya 73,82 . Pada siklus I dicari data menggunakan tes. Dari instrument tersebut diperoleh data tentang nilai siswa dalam pembelajaran siklus I ini sebagai berikut:

Tabel 4.2 Rekapitulasi Hasil Tes pada Siklus I

\begin{tabular}{|c|c|c|c|c|c|}
\hline No & Skor & $\begin{array}{c}\text { Jumlah } \\
\text { Siswa }\end{array}$ & Persentase & Kriteria & Ket \\
\hline 1 & $85-100$ & 4 & 10,53 & Tinggi & T \\
\hline 2 & $75-84$ & 20 & 52,63 & Sedang & T \\
\hline 3 & $65-74$ & 8 & 21,05 & Cukup & BT \\
\hline 4 & $\leq 65$ & 6 & 15,79 & kurang & BT \\
\hline \multicolumn{2}{|c|}{ Jumlah } & 38 & 100,00 & - & - \\
\hline \multicolumn{5}{|c|}{ \%etuntasan } & 63,16 \\
\hline \multicolumn{5}{|c|}{ Rata-rata } & 73,82 \\
\hline
\end{tabular}

Berdasarkan hasil pengamatan pada siklus I ini, dari 38 siswa hanya 24 siswa tuntas belajar dengan presentase ketuntasan sebesar $63,16 \%$ dan nilai rata-rata hasil belajar masih 73,82. Belum tercapainaya indikator keberhasilan penelitian ternyata dipengaruhi oleh karena masih banyaknya siswa yang kurang memperhatikan, hal ini di sebabkan selain metode pembelajaran yang baru di kenal. Dari data dan uraian tersebut dapat di simpulkan bahwa pada siklus I:

a. Karena penggunaan metode pembelajaran yang baru, guru masih canggung saat penyajian materi dengan metode Card Sort. Beberapa siswa ada yang kurang memperhatikan.

b. Saat pembelajaran ada siswa yang kurang aktif. 
c. Terdapat beberapa siswa yang belum mendapatkan nilai sesuai dengan standar ketuntasan. Hal ini di karenakan belum paham dengan materi yang di sampaikan dengan metode Card Sort.

Sehingga dapat disimpulkan bahwa siklus I berjalan dengan baik dan kondusif, walaupun hasil belajar siswa belum mencapai nilai rata-rata 75. Ada beberapa siswa yang belum mencapai target KKM. Oleh karena itu akan dibenahi dan dilanjutkan ke siklus II.

\section{Siklus II}

Pelaksanaan tindakan pada siklus II di laksanakan pada semester II, pada tanggal 1 Maret 2019 dan 8 Maret 2019. Pelaksanaan tindakan ini sesuai dengan program semester mata pelajaran Pendidikan Kewarganegaraan kelas V Semester II, standar kompetensi Memahami Kebebasan Berorganisasi, dengan kompetensi dasar menyebutkan contoh organisasi di lingkungan sekolah dan masyarakat.

Pelaksanaan tindakan pada siklus II ini ada empat tahap, masih seperti tahap sebelumya.

\section{a. Perencanaan}

Pada tahap ini perencanaannya masih seperti tahap 1.

\section{b. Tindakan}

\section{Pertemuan I}

Kegiatan pembelajaran dimulai dengan guru memberi salam.dam mengabsen kehadiran siswa. Guru mengajak siswa membaca basmalah bersama-sama sebelum pelajaran di mulai. Guru kolaborator menyiapkan peralatan pembelajaran Card Sort. Guru memberi penjelasan tentang jalannya metode pembelajaran Card Sort.

Memasuki kegiatan inti Siswa di ajak menyebutkan berbagai organisasi yang ada di lingkungan sekolah dan masyarakat. guru menjelaskan kepada siswa tentang fungsi organisasi- organisasi di sekolah dan masyarakat. Siswa mendengarkan penjelasan guru tentang manfaat bergabung dengan sebuah organisasi di sekolah atau masyarakat. Guru melibatkan siswa secara aktif dalam setiap kegiatan. Guru menjelaskan permainan Card Sort kepada siswa. Guru membagi potongan kertas berisi materi yang di sampaikan kepada siswa. Setiap siswa mendapat satu potongan kertas yang berisi materi yang di sampaikan. Guru menyuruh siswa mencari pasangan yang sesuai dengan materi yang di sampaikan. Jika sudah ada yang ketemu pasangannya, siswa membentuk satu kelompok. Guru meminta semua kelompok untuk mempresentasikan hasilnya secara bergantian. Guru bertanya jawab tentang hal-hal yang belum di ketahui siswa. Guru bersama siswa menyimpulkan materi yang telah di pelajari.

Pada kegiatan akhir guru mengajak siswa membaca hamdalah bersama-sama. Guru mengucapkan salam.

\section{* Pertemuan II}

Kegiatan pembelajaran dimulai dengan guru memberi salam.dam mengabsen kehadiran siswa. Guru mengajak siswa membaca basmalah bersama-sama sebelum pelajaran di mulai. Guru kolaborator menyiapkan peralatan pembelajaran Card Sort. Guru memberi penjelasan tentang jalannya metode pembelajaran Card Sort

Siswa di beri pertanyaan tentang contoh-contoh perilaku baik dan buruk apa saja yang ada, dalam memilih dan memanfaatkan organisasi yang ada di masyarakat. Guru menjelaskan contoh-contoh perilaku yang baik dan buruk dalam memilih dan memanfaatkan organisasi-orgaisasi yang ada di masyaraka. Siswa mendengarkan penjelasan guru tentang manfaat bergabung dengan sebuah organisasi di sekolah atau masyarakat. Guru melibatkan siswa secara aktif dalam setiap kegiatan. Guru menjelaskan 
permainan Card Sort kepada siswa. Selanjutnya membagi potongan kertas berisi materi yang di sampaikan kepada siswa. Setiap siswa mendapat satu potongan kertas yang berisi materi yang di sampaikan. Guru menyuruh siswa mencari pasangan yang sesuai dengan materi yang di sampaikan. Jika sudah ada yang ketemu pasangannya, siswa membentuk satu kelompok.Guru meminta semua kelompok untuk mempresentasikan hasilnya secara bergantian. Guru bertanya jawab tentang hal-hal yang belum di ketahui siswa. Guru bersama siswa menyimpulkan materi yang telah di pelajari.

Pada kegiatan akhir guru memberi evaluasi kepada siswa. Guru memberikan penilaian atau refleksi dari pembelajaran yang sudah di laksanakan. Guru mengajak siswa membaca hamdalah bersama-sama. Guru mengucapkan salam.

\section{c. Pengamatan}

Pada tahap ini dilaksanakan observasi atau pengamatan terhadap pelaksanaan pembelajaran berlangsung, dan pemberian soal tes saat pembelajaran telah selesai.

Pada siklus II ini hampir semua siswa fokus dan memperhatikan materi pembelajaran yang di sampaikan guru, hal ini di karenakan guru melaksanakan pembelajaran dengan metode Card Sort secara maksimal. Selain itu pembelajaran dengan metode Card Sort secara maksimal. Selain itu pembelajaran Card Sort yang di laksanakan pada siklus II sudah tidak asing lagi bagi siswa. Hal itu dapat di lihat dari pengamatan peneliti yang mengamati perhatian siswa dalam mengikuti pembelajaran Card Sort. Selain itu, semua siswa sudah mulai aktif dan paham akan pembelajaran yang menggunakan metode Card Sort. Setelah adanya pengamatan dalam pembelajaran pada siklus II ini didapatkan hasil sebagai berikut:

a. Siswa sudah terbiasa dengan metode pembelajaran Card Sort

b. Sebagian besar siswa sudah benar dalam menjawab soal tes formatif.

c. Guru sudah mulai berinteraksi dengan siswa.

d. Guuru sudah terbiasa menyampaikan materi pembelajaran dengan metode Card Sort.

\section{d. Refleksi}

Berdasarkan hasil pengamatan yang terjadi pada siklus kedua, peneliti menemukan peningkatan yang maksimal dalam prestasi belajar Pendidikan Kewarganegaraan pada siswa kela V SDN 1 Karangsoko Kecamatan Trenggalek sebagai berikut:

1) Kekurangan pada siklus-siklus sebelumnya sudah mengalami perbaikan dan peningkatan sehingga menjadi lebih baik.

2) Prestasi belajar siswa pada siklus II sudah mencapai KKM 75.

3) Jumlah siswa yang memperhatikan semakin banyak karena perlengkapan metode Card Sort dan cara pembelajaran yang di lakukan oleh guru semakin baik, sehingga siswa dapat memperhatikan pelajaran secara maksimal serta prestasi belajar siswa pun menjadi lebih baik.

Dari hasil belajar siswa, terlihat terjadi peningkatan hasil belajar yang cukup signifikan. Pada siklus II ini, nilai siswa sudah memenuhi KKM yang telah di tentukan. Maka pada siklus II dapat di simpulkan bahwa dengan metode Card Sort dapat meningkatkan prestasi belajar PKn pada siswa Kelas V SDN 1 Karangsoko Kecamatan Trenggalek .

Untuk mengetahui tingkat kemampuan siswa di dapat dari hasil evaluasi yang di adakan setelah pembelajaran berlangsung. Adapun hasil tes pada siklus II ini di dapatkan hasil sebagaimana terdapat pada tabel berikut ini: 
Tabel 4.3 Rekapiulasi Hasil Tes pada Siklus II

\begin{tabular}{|c|c|c|c|c|c|}
\hline No & Skor & $\begin{array}{c}\text { Jumlah } \\
\text { Siswa }\end{array}$ & Persentase & Kriteria & Ket \\
\hline $\mathbf{1}$ & $85-100$ & 19 & 50,00 & Tinggi & T \\
\hline $\mathbf{2}$ & $75-84$ & 13 & 34,21 & Sedang & T \\
\hline $\mathbf{3}$ & $65-74$ & 6 & 15,79 & Cukup & BT \\
\hline $\mathbf{4}$ & $\leq 65$ & 0 & 0,00 & kurang & BT \\
\hline & Jumlah & 38 & 100,00 & - & - \\
\hline \% Ketuntasan & \multicolumn{4}{|c|}{84,21} \\
\hline Rata-rata & \multicolumn{4}{|c}{} \\
\hline
\end{tabular}

Berdasarkan uraian tabel di atas di peroleh bahwa nilai tes pada siklus kedua mengalami peningkatan dari nilai tes siklus I, terbukti dari 38 siswa 32 siswa $(84,21 \%)$ tuntas dan 6 siswa $(15,79 \%)$ tidak tuntas. berati ada peningkatan kemampuan siswa dalam hasil belajar siswa. Hal ini di sebabkan karena siswa merasa senang dengan metode Card Sort yang di terapkan oleh guru, sehingga siswa dapat berinteraksi dalam pelaksanaan siklus II ini dan siswa lebih percaya diri dengan baik, baik dengan guru maupun dengan siswa yang lain.

Secara garis besar pelaksanaan siklus II sudah berjalan baik. Dari hasil belajar siswa terjadi peningkatan prestasi siswa dalam menyelesaikan soal, terbukti 32 siswa tuntas $84,21 \%$. Berarti ada peningkatan yang signifikan kemampuan siswa dalam hasil belajar siswa mata pelajaran Pendidikan Kewarganegaraan dengan Materi Memahami Kebebasan Berorganisasi dengan menggunakan Metode Card Sort. Pada siklus II ini sudah di katakan berhasil di lihat dari segi prestasi hasil belajar siswa.

Hasil rekapitulasi (Prestasi Siswa) belajar Pendidikan Kewarganegaraan Melalui strategi pembelajaran Card Sort.

Tabel 4.4 Rekapitulasi Nilai Siswa Per Siklus

\begin{tabular}{|c|c|c|c|}
\hline $\begin{array}{c}\text { Pelaksanaan/ } \\
\text { Ketuntasan }\end{array}$ & Pra Siklus & Siklus I & Siklus II \\
\hline Tuntas & 31,58 & 63,16 & 86,21 \\
\hline Tidak Tuntas & 68,42 & 36,84 & 15,79 \\
\hline Rata-rata & 66,18 & 73,82 & 81,32 \\
\hline
\end{tabular}

Untuk lebih jelasnya berikut ditampilkan grafik peningkatan prestasi belajar siswa pada setiap siklusnya.

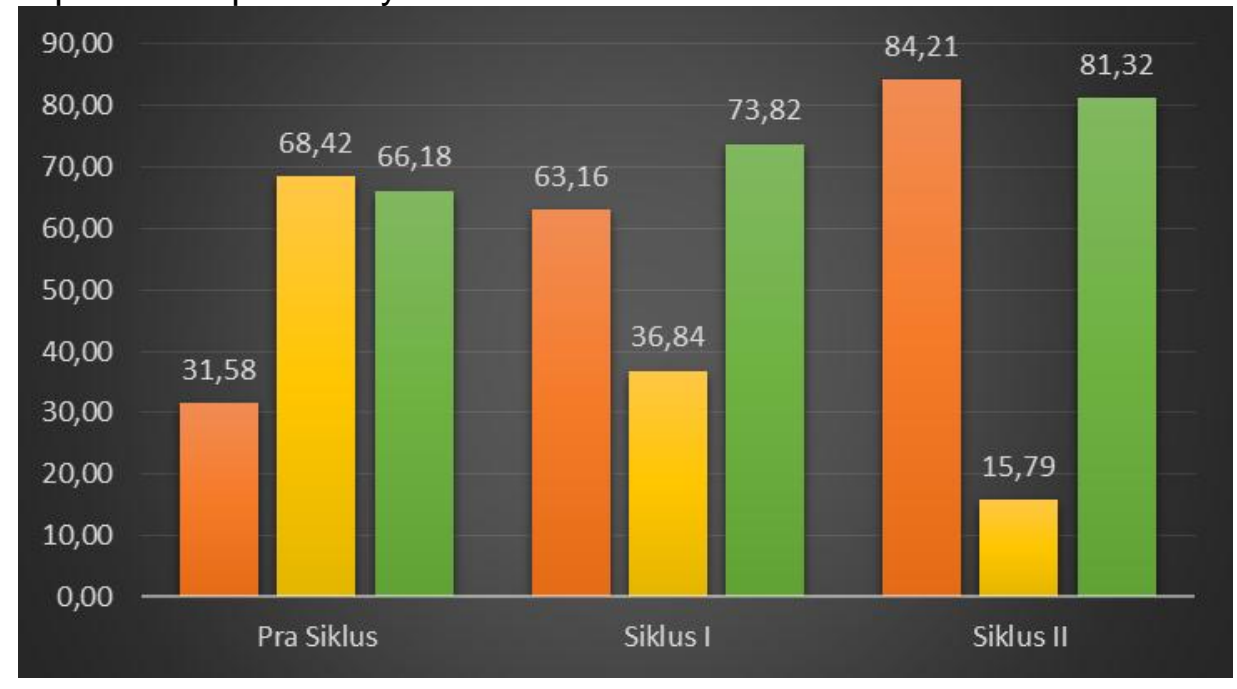

Gambar 4.1 Grafik Peningkatan Prestasi Belajar Siswa Per Siklus 
Dari hasil penelitian dan pembahasan maka dapat di simpulkan bahwa menggunakan metode Card Sort dapat meningkatkan prestasi belajar PKn bagi siswa Kelas V SDN 1 Karangsoko Kecamatan Trenggalek tahun pelajaran 2018/2019. Hal ini di tunjukkan berdasarkan prestasi belajar pada siklus I yaitu hasil rata-rata prestasi belajar pada kondisi awal sebesar 66,18 . Siklus I terjadi peningkatan menjadi 73,82 dan pada siklus II sebesar 81,32 . Sementara ketuntasan belajar juga meningkat dari $31,58 \%$ pada pra siklus, $73,82 \%$ pada siklus I dan 81,32 pada siklus II.

Dari hasil pengamatan kami, ternyata pembelajaran Pendidikan Kewarganegaraan SDN 1 Karangsokon Kecamatan Trenggalek semester II tahun pelajaran 2018/2019 sebelumnya hanya menggunakan metode ceramah dan tanpa menggunakan metode pembelajaran. Hal ini menjadi salah satu faktor penyebab kenapa hasil belajar siswa pada mata pelajaran di sekolah tersebut rendah, hasil belajarnya pun juga kurang dari Kriteria Ketuntasan Minimal (KKM) yang telah ditentukan.

Setelah diadakanya pembelajaran Pendidikan Kewarganegaraan dengan menggunakan metode Card Sort di SDN 1 Karangsokon Kecamatan Trenggalek Semester II tahun pelajaran 2018/2019 dapat kita lihat ternyata perhatian siswa dalam mengikuti pembelajaran Pendidikan Kewarganegaraan cukup tinggi, meskipun pada awalnya (Siklus I) hanya beberapa siswa saja yang memperhatikan dan hasil belajar pada saat test formatif juga masih kurang dari KKM yang telah ditentukan, itu selain dikarenakan media dan model pembelajaran yang baru mereka kenal, juga disebabkan karena banyak siswa yang tidak fokus terhadap instruksi guru mengenai mekanisme penerapan metode Card Sort.

Berdasarkan uraian di atas dapat menjawab hipotesis yang menyatakan bahwa dengan menggunakan Metode Card Sort dapat meningkatkan prestasi belajar siswa dalam mata pelajaran PKn materi memahami kebebasan berorganisasill bagi siswa kelas V SDN 1 Karangsoko Kecamatan Trenggalek Kabupaten Trenggalek semester II tahun pelajaran 2018/2019, di terima kebenarannya. Dan dari hasil belajar siswa di atas dapat membuktikan bahwa pembelajaran ini efektif meningkatkan prestasi belajar pada siswa.

\section{KESIMPULAN}

Berdasarkan hasil penelitian dan pembahasan maka dapat disimpulkan bahwa dengan menggunakan metode Card Sort dapat meningkatkan prestasi belajar PKn bagi siswa kelas V SDN 1 Karangsoko Kecamatan Trenggalek Kabupaten Trenggalek semester 2 tahun pelajaran 2018/2019. Hal ini ditunjukkan berdasarkan dari ketuntasan belajar siswa. Jumlah siswa yang mencapai nilai KKM pada pra siklus sebanyak 12 siswa (31,58\%), siklus I sebanyak 24 siswa $(63,16 \%)$ dan siklus II sebanyak 32 siswa $(84,21 \%)$. Sedangkan pencapaian nilai rata-rata kelas pada pra siklus adalah 66,18, siklus I adalah 73,82, pada siklus II adalah 81,32.

\section{DAFTAR RUJUKAN}

Ahmad, Susanto. (2013). Teori Belajar dan Pembelajaran di Sekolah Dasar. Jakarta: Kencana Prenadamedia Group

Hisyam, Zaini. (2002). Strategi Pembelajaran Aktif di PT Yogyakarta: CTDS.

Kemmis, S \& Mc Taggart, R. (1992).The Action Research Planner. Australia:Deakin University Press

Sanjaya, Wina. (2014). Strategi Pembelajaran Berorientasi Standar Proses Pendidikan. Jakarta: Kencana Penanda Media Group.

Sutikno, Sobry. (2014). Metode dan Model-model Pembelajaran. Lombok: Holistica Lombok.

Syah, Muhibbin. (2010). Psikologi Belajar. Jakarta: PT Raja Grafindo Persada. 